\title{
HUBUNGAN PENDAPATAN ORANG TUA DAN STATUS GIZI TERHADAP USIA MENARCHE
}

\author{
Syarifah Rahmi Asfahani ${ }^{1}$, Raja Fitrina Lestari $^{2}$, Dian Roza Adila ${ }^{3}$ \\ ${ }^{1,2,3}$ Program Studi Ilmu Keperawatan \\ STIKes Hang Tuah Pekanbaru \\ Jl. Mustafa Sari No. 5 Tangkerang Selatan Pekanbaru \\ E-mail: stikes.htp@gmail.com
}

\begin{abstract}
Abstrak
Usia menarche adalah usia pertama kali menstruasi. Di Indonesia terjadi penurunan usia menarche sekitar $5,2 \%$. Percepatan dan perlambatan usia menarche mempunyai beberapa konsekuensi yang berkaitan dengan aspek biologis dan lingkungan. Usia menarche dipengaruhi oleh banyak faktor, diantaranya adalah faktor gizi dan pendapatan orang tua. Penelitian ini bertujuan untuk mengetahui hubungan pendapatan orang tua dan status gizi terhadap usia menarche. Jenis penelitian ini adalah penelitian kuantitatif dengan desain retrospektif. Sampel penelitian sebanyak 193 dengan menggunakan teknik purposive sampling. Alat ukur yang digunakan lembar kuesioner. Analisis yang digunakan adalah analisis univariat dan bivariat dengan menggunakan uji pearson chi-square. Hasil penelitian diperoleh tidak terdapat hubungan antara pendapatan orang tua dengan usia menarche dengan $p$-value $=0,549$ dan tidak terdapat hubungan antara status gizi dengan usia menarche dengan $p$-value $=0,376$. Disarankan kepada siswi untuk lebih aktif dalam menggali informasi mengenai kesehatan reproduksi terutama tentang menarche.
\end{abstract}

Kata kunci : Usia menarche, Pendapatan Orang Tua, Status gizi

\begin{abstract}
The age of menarche is the first age of menstruation. In Indonesia there is a decline in menarche age of around 5.2\%. The velocity and decelaration of menarche age have a consequence that is related to biological and environmental aspect. The menarche age is influenced by some factors, including nutrition factors and parent's income. This research aims to know the correlation between parent's income and the nutrition toward menarche age. The research is quantitative research design with retrospective design. Sample of the research consists of 193 female student using purposive sampling technique. The instrument of this research is by giving a questionnaire. The analysis used is univariate and bivariate analysis with pearson chi-square examination. The result of this research is that there is no correlation between parent's income and the age of menarche with $p$-value $=0,549$ and there is no correlation between nutrition status and the age of menarche with $p$-value $=0,376$. The suggestion is that the female students have to be more active in searching for information regarding reproduction health especially menarche.
\end{abstract}

Keywords : Age of menarche, Parent's income, Nutritional status

\section{PENDAHULUAN}

Menarche adalah menstruasi pertama kali yang terjadi pada seorang wanita, dan paling sering terjadi pada usia 11 tahun. Menstruasi yaitu pelepasan dinding rahim (endometrium) yang disertai dengan keluarnya darah dari vagina dan terjadi secara berulang setiap bulan kecuali pada seorang wanita yang hamil. Menstruasi juga sebagai pertanda masa reproduktif pada kehidupan seorang wanita yang dimulai dari menarche sampai menopause (Prayitno, 2014).

Usia mendapatkan menarche disetiap negara berbeda-beda. Wanita di Negara maju 
Syarifah Rahmi Asfahani, Raja Fitrina Lestari ${ }^{2}$, Dian Roza Adila ${ }^{3}$, Hubungan Pendapatan Orang Tua dan Status Gizi terhadap Usia Menarche

seperti Amerika mengalami menarche rata-rata pada usia 12,8 tahun dan di China rata-rata pada usia 17 tahun (Rosenthal, 2009). Sedangkan di Asia Tenggara seperti Thailand rata-rata wanita mendapatkan menarche pada usia 12,5 tahun (Karapanou \& Papaditrimou, 2010). Rata-rata Di Indonesia usia menarche 12,8 tahun (Khusen, 2013).

Seiring dengan kemajuan zaman, usia menarche bergeser ke usia yang lebih muda. Data Riskesdas (2010), menunjukkan Indonesia mengalami penurunan usia menarche dibawah usia 12 tahun sebanyak 5,2\% remaja di 17 Provinsi. Percepatan usia menarche mempunyai beberapa konsekuensi yang dapat berkaitan dengan aspek biologis dan lingkungan. Remaja dengan menarche dini mengalami kematangan organ reproduksi lebih cepat, hal ini mengakibatkan meningkatnya aktifitas seksual lebih dini, sehingga mempunyai resiko kehamilan yang tidak diinginkan akibat hubungan seks pranikah dikalangan remaja yang dapat menimbulkan peningkatan aborsi pada remaja (Aryati, 2008). Selain itu, usia menarche yang lebih dini terutama di bawah 10 tahun juga dapat beresiko terjadinya kanker rahim maupun payudara (Olivia, 2013).

Usia menarche lebih awal atau lebih lambat dapat dipengaruhi oleh banyak faktor yaitu ras, suku, genetik, gizi, sosial ekonomi, media dewasa, perilaku seksual dan gaya hidup (Wiknjosastro, Saifuddin \& Rachimhadhi, 2009). Apabila status gizi wanita baik, maka tidak akan ada hambatan dalam sistem reproduksinya, sebaliknya jika kekurangan gizi maka akan berdampak pada penurunan fungsi reproduksi (Sibagariang, 2010). Status gizi sering kali dihubungkan dengan pendapatan orang tua, pendapatan orang tua merupakan kemampuan orang tua dalam memenuhi kebutuhan gizi remaja, pemenuhan gizi remaja dapat berkaitan dengan kematangan seksual pada remaja. Oleh karena itu, keluarga yang mempunyai pendapatan lebih dari cukup, secara otomatis mempengaruhi keadaan status gizi remaja yang berkaitan erat dengan cepatnya usia menarche (Putri, 2009).

Berdasarkan survei awal yang dilakukan di SMPN 8 Pekanbaru, terhadap 8 orang didapatkan 4 orang menarche pada usia di bawah 11 tahun, 3 orang menarche pada usia 12 tahun dan 1 orang belum mengalami menarche dengan usianya 14 tahun.

Berdasarkan uraian di atas, peneliti tertarik untuk melakukan penelitian tentang "Hubungan pendapatan orang tua dan status gizi terhadap usia menarche".

\section{METODE PENELITIAN}

Jenis penelitian ini adalah penelitian kuantitatif dengan menggunakan desain pendekatan Retrospektif. Penelitian dilakukan di SMPN 8 Pekanbaru pada 11 Mei 2018. Sampel penelitian sebanyak 166 orang siswi kelas VII dan VIII dengan teknik purposive sampling. Alat ukur yang digunakan lembar kuesioner. Analisa yang digunakan adalah 
analisa univariat dan bivariat dengan menggunakan uji pearson chi-square.

\section{HASIL PENELITIAN}

\section{Analisis Univariat}

Distribusi frekuensi karakteristik responden: Umur responden, Usia menarche, pendapatan orang tua, Jumlah saudara dan Status gizi di SMP Negeri 8 Pekanbaru, disajikan pada tabel 1 .

Tabel 1

Distribusi frekuensi karakteristik responden

\begin{tabular}{|c|c|c|c|}
\hline No & Kategori & (n) & $(\%)$ \\
\hline \multicolumn{4}{|c|}{ Usia Responden } \\
\hline 1 & 11 Tahun & 18 & 10,8 \\
\hline 2 & 12 Tahun & 28 & 16,9 \\
\hline 3 & 13 Tahun & 60 & 36,1 \\
\hline 4 & 14 Tahun & 51 & 30,7 \\
\hline 5 & 15 Tahun & 7 & 4,2 \\
\hline 6 & 16 Tahun & 2 & 1,2 \\
\hline \multicolumn{4}{|c|}{ Usia menarche } \\
\hline 1 & Normal & 164 & 98,8 \\
\hline 2 & Lambat & 2 & 1,2 \\
\hline \multicolumn{4}{|c|}{ Pendapatan Orang Tua } \\
\hline 1 & Sangat tinggi & 6 & 3,6 \\
\hline 2 & Tinggi & 77 & 46,6 \\
\hline 3 & Sedang & 45 & 27,1 \\
\hline 4 & Rendah & 38 & 22,9 \\
\hline No & Kategori & (n) & $(\%)$ \\
\hline
\end{tabular}

\begin{tabular}{|c|c|c|c|}
\hline No & Kategori & (n) & $(\%)$ \\
\hline \multicolumn{4}{|c|}{ Jumlah saudara } \\
\hline 1 & Anak tunggal & 28 & 16,9 \\
\hline 2 & 2 orang & 63 & 38,0 \\
\hline 3 & 3 orang & 40 & 24,1 \\
\hline 4 & 4 orang & 33 & 19,9 \\
\hline 5 & $>4$ orang & 2 & 1,2 \\
\hline \multicolumn{4}{|c|}{ Status Gizi } \\
\hline 1 & Kurus & 39 & 23,5 \\
\hline 2 & Normal & 81 & 48,8 \\
\hline 3 & Gemuk & 46 & 27,7 \\
\hline & Total & 166 & 100 \\
\hline
\end{tabular}

Berdasarkan tabel 1 diatas dapat disimpulkan bahwa dari 166 responden mayoritas berumur 13 tahun sebanyak 60 orang $(36,1 \%)$, mayoritas responden mendapatkan usia menarche normal sebanyak 164 orang $(98,8 \%)$, mayoritas responden yang mempunyai orang tua dengan pendapatan tinggi sebanyak 83 orang (50\%), mayoritas responden dengan jumlah saudara 2 orang sebanyak 63 orang $(38,0 \%)$ dan sebagian besar responden memiliki status gizi normal sebanyak 81 orang $(48,8 \%)$.

Tabel 2

Hubungan pendapatan orang tua terhadap usia menarche di SMP Negeri 8 Pekanbaru

\begin{tabular}{|c|c|c|c|c|c|c|c|}
\hline \multirow{3}{*}{ Pendapatan Orang Tua } & \multicolumn{6}{|c|}{ Usia menarche } & \multirow{3}{*}{ P Value } \\
\hline & \multicolumn{2}{|c|}{ Normal } & \multicolumn{2}{|c|}{ Lambat } & \multicolumn{2}{|c|}{ Total } & \\
\hline & $\mathbf{n}$ & $\%$ & $\mathbf{n}$ & $\%$ & $\mathbf{n}$ & $\%$ & \\
\hline $\begin{array}{l}\text { Tinggi } \\
\text { (Rp. 2.500.000,00 s/d } \\
\text { Rp.3.500.000,00 per bulan) }\end{array}$ & 82 & 98,8 & 1 & 1,2 & 83 & 100 & 0,549 \\
\hline $\begin{array}{l}\text { Sedang } \\
\text { (Rp. } 1.500 .000,00 \mathrm{~s} / \mathrm{d} \\
\text { Rp. } 2.500 .000,00 \text { per bulan) }\end{array}$ & 45 & 100,0 & 0 & 0,0 & 45 & 100 & \\
\hline $\begin{array}{l}\text { Rendah } \\
(\leq \text { Rp. } 1.500 .000,00 \text { per bulan. })\end{array}$ & 37 & 97,4 & 1 & 2,6 & 38 & 100 & \\
\hline Total & 164 & 98,8 & 2 & 1,2 & 166 & 100 & \\
\hline
\end{tabular}


Syarifah Rahmi Asfahani', Raja Fitrina Lestari ${ }^{2}$, Dian Roza Adila ${ }^{3}$, Hubungan Pendapatan Orang Tua dan Status Gizi terhadap Usia Menarche

Berdasarkan tabel 2 diatas diketahui bahwa responden dengan orang tua berpendapatan tinggi, yang mengalami usia menarche normal 82 orang $(98,8 \%)$ dan yang mengalami usia menarche lambat 1 orang $(1,2 \%)$. Responden dengan orang tua berpendapatan sedang, yang mengalami usia menarche normal 45 orang (100\%) dan tidak ada responden yang mengalami usia menarche lambat. Sedangkan responden dengan orang tua berpendapatan rendah, yang mengalami usia menarche normal 37 orang $(97,4 \%)$ dan yang mengalami usia menarche lambat 1 orang $(2,6 \%)$. Hasil uji pearson chisquare didapat $p_{\text {value }} 0,549(>0,05)$ hal ini menunjukkan tidak ada hubungan antara pendapatan orang tua dengan usia menarche.

Tabel 3

Hubungan status gizi terhadap usia menarche di SMP Negeri 8 Pekanbaru

\begin{tabular}{|c|c|c|c|c|c|c|c|}
\hline \multirow{3}{*}{ Status Gizi } & \multicolumn{6}{|c|}{ Usia menarche } & \multirow{3}{*}{ P Value } \\
\hline & \multicolumn{2}{|c|}{ Normal } & \multicolumn{2}{|c|}{ Lambat } & \multicolumn{2}{|c|}{ Total } & \\
\hline & $\mathbf{n}$ & $\%$ & $\mathbf{n}$ & $\%$ & n & $\%$ & \\
\hline $\begin{array}{l}\text { Kurus } \\
\text { (-3 SD sampai <-2 SD) }\end{array}$ & 38 & 97,4 & 1 & 2,6 & 39 & 100 & 0,376 \\
\hline $\begin{array}{l}\text { Normal } \\
\text { (-2 SD sampai } 1 \mathrm{SD})\end{array}$ & 81 & 100 & 0 & 0,0 & 81 & 100 & \\
\hline $\begin{array}{l}\text { Gemuk } \\
\text { (>1 sampai } 2 \mathrm{SD})\end{array}$ & 45 & 97,8 & 1 & 2,2 & 46 & 100 & \\
\hline Total & 164 & 98,8 & 2 & 1,2 & 166 & 100 & \\
\hline
\end{tabular}

Berdasarkan tabel 3 diatas diketahui bahwa responden yang memiliki status gizi kurus, yang mengalami usia menarche normal 38 orang $(97,4 \%)$ dan yang mengalami usia menarche lambat 1 orang (2,6\%). Responden yang memiliki status gizi normal, yang mengalami usia menarche normal 81 orang $(100 \%)$ dan tidak ada responden yang mengalami usia menarche lambat. Sedangkan responden yang memiliki status gizi gemuk, yang mengalami usia menarche normal 45 orang $(97,8 \%)$ dan yang mengalami usia menarche lambat 1 orang (2,2\%). Hasil uji pearson chi-square didapat $p_{\text {value }} 0,376$ (> 0,05) hal ini berarti tidak terdapat hubungan antara status gizi dengan usia menarche.

\section{PEMBAHASAN}

Berdasarkan hasil penelitian didapatkan hasil sebagian besar responden berusia 13 tahun sebanyak 60 orang $(36,1 \%)$. Lestari (2011) menjelaskan pada usia 12 tahun mulai dihasilkan hormon GnRH (Gonadotrophic hormone) kemudian mencapai kelenjar pituitary dan menghasilkan dua jenis hormon yaitu FSH (follicle-stimulating hormone) dan LH (luteinizing hormone) yang mempunyai efek sangat besar terhadap kematangan seksual remaja putri, sehingga pada usia inilah kebanyakan remaja mengalami menarche.

Berdasarkan hasil penelitian didapatkan sebagian besar usia menarche dalam kategori normal (11-15 tahun) sebanyak 164 orang $(98,8 \%)$. Hasil penelitian ini sesuai dengan 
teori Manuaba (2009) yang mengatakan usia menarche normalnya terjadi pada usia 11 sampai 15 tahun. Data Riskesdas (2010) menunjukkan bahwa rata-rata usia menarche di Indonesia adalah 13 tahun, secara nasional rata-rata usia menarche 13-14 tahun terjadi pada $37,5 \%$ anak Indonesia.

Berdasarkan hasil penelitian dapat diketahui sebagian besar orang tua responden memiliki pendapatan tinggi sebanyak 77 orang $(46,6 \%)$. Pendapatan orang tua sangat berpengaruh besar dalam kehidupan, terutama dalam kebutuhan pokok seperti sandang, pangan, dan papan. Pendapatan orang tua juga sangat berkaitan erat dengan pemenuhan status gizi anak yang akan berdampak pada pertumbuhan anak terutama pertumbuhan organ reproduksi. Selain itu pendapatan orang tua juga dapat berpengaruh dalam pendidikan, seperti sarana dan prasarana sekolah yang diperlukan dalam proses belajar.

Berdasarkan hasil penelitian diketahui sebagian besar responden memiliki status gizi dalam kategori normal sebanyak 81 orang (48,8\%). Kategori dan ambang batas status gizi anak berdasarkan IMT/U yang termasuk kriteria gizi normal yaitu berada pada standar 2 SD sampai dengan 1 SD (Kemenkes RI, 2011). Hasil penelitian ini mendukung Riskesdas (2010) yang menunjukkan bahwa status gizi anak perempuan Indonesia, pada usia 6 sampai 12 tahun (IMT/U) mayoritas berada pada kategori normal sebanyak $81,1 \%$. Sedangkan status gizi anak perempuan pada usia 13 sampai 15 tahun (IMT/U) mayoritas berada pada kategori normal yaitu sebanyak $67,5 \%$.

Berdasarkan hasil penelitian, peneliti berasumsi bahwa diperolehnya hasil sebagian besar responden dalam kelompok usia 12 hingga 14 tahun, hal ini dikarenakan sesuai dengan kriteria inklusi bahwa responden yang diambil adalah kelas VII dan VIII yang ratarata berusia 12 sampai 14 tahun. Berdasarkan hasil penelitian juga didapatkan sebagian besar usia menarche normal dan status gizi responden normal, hal ini didukung dengan sebagian besar responden memiliki orang tua dengan pendapatan tinggi yang mana akan memicu tingkat daya beli yang tinggi pula, sehingga terpenuhinya kebutuhan gizi remaja yang dapat berpengaruh pada usia menarche dalam kategori normal.

\section{Hubungan pendapatan orang tua terhadap usia menarche}

Berdasarkan penelitian tidak ada hubungan antara pendapatan orang tua dengan usia menarche $\left(p_{\text {value }}=0,549\right)$. Hasil penelitian ini sejalan dengan penelitian yang dilakukan Aisya (2016) yang menunjukkan tidak terdapat hubungan antara pendapatan orang tua dengan usia menarche. Hasil penelitian ini berbeda dengan penelitian yang dilakukan oleh Mutasya (2016) bahwa terdapat hubungan antara tingkat pendapatan per kapita dengan usia menarche. Perbedaan hasil penelitian dapat dikarenakan usia menarche tidak hanya dipengaruhi oleh faktor pendapatan orang tua. Banyak faktor yang mempengaruhi usia menarche, salah satunya 
Syarifah Rahmi Asfahani, Raja Fitrina Lestari ${ }^{2}$, Dian Roza Adila ${ }^{3}$, Hubungan Pendapatan Orang Tua dan Status Gizi terhadap Usia Menarche

adalah lingkungan sosial. Menurut Sukarni dan Margareth (2013), remaja dengan lingkungan keluarga yang harmonis dapat memperlambat terjadinya menarche, sedangkan remaja yang tinggal bersama keluarga yang tidak harmonis dapat mempercepat usia menarche.

Fikawati (2017), menyatakan orang tua dengan pendapatan tinggi akan memiliki anggota keluarga dengan status gizi yang baik pula, sehingga akan berdampak pada pertumbuhan dan perkembangan seksual yang berpengaruh pada usia menarche. Walaupun demikian, tidak selalu pendapatan tinggi menjamin terpenuhinya semua kebutuhan gizi. Sebagai contoh remaja yang menderita anoreksia nervosa banyak yang berasal dari keluarga dengan orang tuanya berpendapatan tinggi, sehingga pertumbuhan dan perkembangan remaja tersebut terganggu.

Dalam penelitian ini menunjukkan hampir semua responden yang orang tuanya berpendapatan rendah mengalami usia menarche dalam kategori normal. Menurut peneliti, hal ini mungkin dipengaruhi dari jumlah saudara responden. Rendahnya pendapatan orang tua namun tanggungan biaya hidup tidak besar maka dapat lebih terpenuhinya kebutuhan makanan, informasi yang didapat bahkan fasilitas pada remaja yang mana nantinya dapat berpengaruh pada pertumbuhan dan kematangan seksualnya. Hal ini dibuktikan dari 38 responden yang berpendapatan rendah, responden yang mempunyai jumlah saudara $<3$ orang sebanyak 32 orang.

\section{Hubungan status gizi terhadap usia menarche}

Berdasarkan penelitian tidak terdapat hubungan antara status gizi terhadap usia menarche dengan $p_{\text {value }}=0,376(>0,05)$. Hasil penelitian ini sejalan dengan penelitian yang dilakukan Wulandari dan Ungsianik (2013) yang menunjukkan tidak terdapat hubungan antara status gizi dengan usia menarche pada remaja putri.

Remaja putri yang terpelihara kadar gizinya akan terjaga kesehatan reproduksinya. Namun tidak menutup kemungkinan bila remaja yang status gizinya kurang atau lebih kesehatan reproduksinya tetap terjaga. Proverawati dan Misaroh (2009) juga mengatakan kualitas gizi yang lebih baik dapat memicu terjadinya menarche dini, tetapi gizi yang kurang juga dapat mengakibatkan menarche dini. Hal ini dikarenakan usia menarche tidak hanya di pengaruhi oleh status gizi namun di pengaruhi oleh banyak faktor yang lainnya.

Menurut Irianto (2014) usia menarche sangat erat hubungannya dengan usia menarche ibu, dan lebih erat lagi antar usia menarche saudara perempuannya. Sukarni dan Margareth (2013) mengatakan faktor penyebab menarche juga datang dari rangsangan audio visual, baik berasal dari percakapan maupun tontonan dari film-film atau akses internet berlabel dewasa, vulgar atau mengumbar 
sensualitas. Rangsangan dari mata dan telinga tersebut akan merangsang sistem reproduksi dan genetalia menjadi lebih cepat matang.

Dalam sistem reproduksi seorang remaja selain dibutuhkan nutrisi yang baik, juga dipengaruhi oleh faktor psikologi. Jika seorang remaja mengalami psikologi meskipun status gizinya baik maka sistem reproduksinya bisa terganggu. Misalnya stress, ini dapat mempengaruhi kesuburan seorang remaja yang secara tidak menutup kemungkinan dapat mempengaruhi usia menarche remaja (Sibagariang, 2010).

Remaja putri yang mempunyai latihan keras seperti seorang atlet dapat terjadi menarche lebih lambat di bandingkan remaja yang bukan seorang atlet. Aktivitas fisik yang berlebihan dapat meningkatkan massa otot dibandingkan massa timbunan lemak, sehingga meskipun berat badan bertambah, tidak akan memberikan pengaruh kepada peningkatan persentase lemak tubuh dan mengurangi jumlah jaringan lemak yang berguna untuk menghasilkan leptin yang dapat mempengaruhi menarche (Fikawati, 2017).

Pada hasil penelitian ini dan penjelasan diatas dapat disimpulkan bahwa usia menarche dalam kategori normal dapat terjadi pada siswi dengan segala status gizi seperti, normal, kurus maupun gemuk. Status gizi bukanlah merupakan satu-satunya faktor yang mempengaruhi usia menarche.

\section{SIMPULAN}

Berdasarkan hasil penelitian dapat disimpulkan bahwa sebagian besar responden berumur 13 tahun, sebagian besar responden mengalami usia menarche normal, sebagian besar responden mempunyai orang tua dengan pendapatan tinggi, sebagian besar responden memiliki jumlah saudara 2 orang dan sebagian besar responden memiliki status gizi normal. Hasil uji statistik menunjukkan bahwa tidak terdapat hubungan antara pendapatan orang tua dengan usia menarche di SMP Negeri 8 Pekanbaru dengan $p_{\text {value }}=0,549(>0,05)$ dan tidak terdapat hubungan antara status gizi dengan usia menarche di SMP Negeri 8 Pekanbaru dengan $p_{\text {value }}=0,376(>0,05)$.

\section{DAFTAR PUSTAKA}

Aisya, M. (2016). Hubungan gaya hidup dengan kejadian menarche di SMA Negeri 1 Driyorejo Kabupaten Gresik. Skripsi tidak dipublikasikan

Aryati, D. (2008). Usia menarche pada siswi SD dan SLTP di kota Bandung. Jurnal Kesehatan Masyarakat Nasional. 2(6), 244. Diperoleh dari http://jurnalkesmas.ui.ac.id/kesmas/article /view/243

Fikawati, S. (2017). Gizi anak dan remaja. Depok: Rajawali Pers.

Irianto, K. (2014). Gizi seimbang dalam kesehatan reproduksi. Bandung: Alfabeta.

Kementerian Kesehatan Republik Indonesia. (2011). Standar antropometri penilaian status gizi anak. Jakarta: Kementrian Kesehatan RI.

Khusen, D. (2013). Rahasia kesehatan wanita. Badan Penerbit FKUI: Jakarta.

Lestari, N. (2011). Tips praktis mengetahui masa subur. Yogyakarta: Katahati.

Manuaba, I. G. D. (2009). Memahami kesehatan reproduksi wanita. Jakarta: EGC. 
Syarifah Rahmi Asfahani', Raja Fitrina Lestari ${ }^{2}$, Dian Roza Adila ${ }^{3}$, Hubungan Pendapatan Orang Tua dan Status Gizi terhadap Usia Menarche

Mutasya, F. U., Edison., \& Hasyim, H. (2016). Faktor-faktor yang berhubungan dengan usia menarche siswi SMP Adabiyah. Jurnal Kesehatan Andalas, 5(1), 233-237. Diperoleh dari http://jurnal.fk.unand.ac.id/index.php/jka/ article/view/475

Noviana, N. (2014). Kesehatan reproduksi untuk mahasiswa kebidanan. Jakarta: CV. Trans Info Media.

Olivia, F. (2013). Mengatasi gangguan haid. Jakarta: Media Komputindo.

Prayitno, S. (2014). Buku lengkap kesehatan organ reproduksi wanita. Yogyakarta: Saufa.

Proverawati, A., \& Misaroh, S. (2009). Menarche: Menstruasi pertama penuh makna. Yogyakarta: Nuha Medika

Putri, A. K. (2009). Hubungan antara status gizi, status menarche ibu, media massa, aktifitas olahraga dengan status menarche siswi di SMP islam al-azhar Rawamangun, jakarta timur. Skripsi tidak dipublikasikan.

Riset Kesehatan Dasar (2010). Kesehatan reproduksi: Masa Reproduksi Perempuan. Jakarta: Kementrian Kesehatan RI.

Riset Kesehatan Dasar (2010). Gizi: Status gizi anak umur 6-12 tahun dan status gizi anak umur 13-15 tahun. Jakarta: Kementrian Kesehatan RI.

Rosenthal, M. S. (2009). Revolusi terapi hormon. Yogyakarta: B-frist.

Safitri, D., Arneliwati., \& Erwin. (2014). Analisis indikator gaya hidup yang berhubungan dengan usia menarche remaja putri. JOM PSIK, 1(2), 1-8. Diperoleh dari https://jom.unri.ac.id/index.php/JOMPSIK /article/download/3395/3292

Sibagariang, E. E. (2010). Gizi dalam kesehatan reproduksi. Jakarta: Trans Info Media.

Sukarni, K. I., \& Margareth. ZH. (2013). Kehamilan, persalinan, dan nifas. Yogyakarta: Nuha Medika.

Wiknjosastro, H., Saifuddin, A. B., \& Rachimhadhi, T. (2009). Ilmu kandungan. Jakarta: Bina Pustaka Sarwono Prawirohardjo.
Wulandari, S., \& Ungsianik, T. (2013). Status gizi, aktivitas fisik, dan usia menarche remaja putri. Jurnal Keperawatan Indonesia, 16(1), 56-58. Diperoleh dari https://www.neliti.com/id/publications/10 6049/status-gizi-aktivitas-fisik-dan-usiamenarche-remaja-putri 